\title{
Internal Audit and Trust of Donors in Developing Countries: The Case of Benin
}

\author{
N'djibio Kokou Charlemagne*, Sylla Doucouré Karima \\ Finance, Entrepreneurship and Accounting Laboratory (LaFEC) of Doctoral School of Economic Sciences and Management, Faculty of \\ Economic Sciences and Management (FASEG), University of Abomey Calavi (UAC), Cotonou, Benin
}

Email address:

ndjibioc@gmail.com (N. K. Charlemagne), karimasylla@yahoo.fr (S. D. Karima)

${ }^{*}$ Corresponding author

\section{To cite this article:}

N'djibio Kokou Charlemagne, Sylla Doucouré Karima. Internal Audit and Trust of Donors in Developing Countries: The Case of Benin. International Journal of Accounting, Finance and Risk Management. Vol. 6, No. 1, 2021, pp. 16-24. doi: 10.11648/j.ijafrm.20210601.13

Received: April 8, 2020; Accepted: April 28, 2020; Published: February 27, 2020

\begin{abstract}
The main objective of this paper is to determine the impact of internal audit on the trust of Donors (Technical and Financial Partners) of Developing Countries, especially those of Benin. It has two specific objectives: to measure the impact of internal audit on the performance of public administrations; and assess the influence of the performance of public administrations on the confidence of Benin's donors. The central hypothesis is that internal audit improves the confidence of state donors. It is broken down into two secondary hypotheses which are presented as follows: internal audit positively influences the performance of public administrations in Benin; and the performance of public administrations positively influences the confidence of donors. The double difference model is used to estimate the impact of internal audit. The study reveals that internal audit positively influences the performance of public administration in Benin. It also reveals that the performance of public administrations has a positive impact on the trust of Donors (Technical and Financial Partners) in Benin. Our research work proposes within the framework of the implementation of New Public Management prescriptions and public finance reforms, the generalization of the implementation of internal audit in all public administrations of developing countries. The implementation of internal audit would therefore serve to boost the trust of State donors and thus give them assurance as to the proper management of Public Development Aid (PDA) and External Loans.
\end{abstract}

Keywords: Internal Audit, Donor’s Trust, Performance, Public Administration

\section{Introduction}

The global financial and economic crisis that started in spring 2007 has placed the theme of trust at the center of global public debate: trust in interbank relations, trust of households and businesses in the future, market's trust in the signing of public authority, trust of donors. From this verbal profusion emerges two problems that will guide this article: the importance, which appears considerable, of trust in "interstate relations" and in "relations between" donors and States ", manifests itself by the disappearance of it; it also seems rather difficult to know exactly what this notion covers, the plastic use of which seems to mask great confusion. Confidence is signaled by its absence and would remain elusive when it exists. The importance given by an increasingly voluminous research to the notion of trust is moreover inversely proportional to the precision, on average, of theoretical conceptions and empirical instruments used.

As Hardin (2006) [1] notes, it is because of fear of its decline that the social sciences are interested in the notion of trust in modern societies. We will find, as always, distant precursors (starting with Georg Simmel), but it seems reasonable to trace the scientific news of this concern to fifteen years, and to the publication of a book and a article by Robert Putnam (1993, 1995) [2, 3] and a work by Francis Fukuyama (1995) [4].

UNCTAD estimates that implementing the 2030 Agenda will cost about $\$ 2.5$ trillion a year in developing countries. To reach the first sustainable development objective by 2030 , which concerns the eradication of poverty, the gross domestic product of the African continent should increase by more than $15 \%$ per year (assuming that savings, investment foreign direct and official development assistance will remain at current levels). Even taking into account only investment in 
infrastructure - the major bottleneck of economic transformation and sustainable growth - financing needs are $\$ 5,000-7$ trillion a year globally. In developing countries, the infrastructure funding gap is estimated to be between $\$ 1$ trillion and \$ 1.4 trillion per year (A. Bhattacharya and M. Romani, 2013) [5].

International public finance and effective international cooperation therefore have an important role to play in achieving the goals, but domestic public resource mobilization and domestic and international private capital flows are also essential to fill the financing gap.

To better manage development aid funds and more deserve the trust of donors, African states like Western countries (United States, Canada, United Kingdom, France and others) have embarked on a long process of public finance reforms with a vision of optimizing the resources they have to meet the needs of the populations. This is how the Council of Ministers in the West African Monetary and Economic Union (WAEMU) adopted in March and June 2009, six Directives renewing the Harmonized Framework of Public Finances within the Union, following a long participative process animated by the experts States and representatives of the WAEMU Commission and Technical and Financial Partners. The new Harmonized Public Finance Framework within WAEMU is based on these six (6) Directives including Directive No. 06/2009 / CM / UEMOA on the finance law within WAEMU (LOLF Directive, 2009) [6] which has been transposed into Organic Law in Benin (LOLF, 2013) [7].

Internal auditors in the public sector can play an important role in creating added value in the administration of development aid programs and the management of allocations by providing assurance as to the deployment and use of this aid in accordance with the rules, regulations and conditions stipulated in the agreements, by the granting body or in all legal or jurisdictional obligations which apply to the granting bodies or to the beneficiaries. The involvement of the internal audit can be done by proactive evaluations (advisory missions) to provide insight and allow anticipation of future repercussions, or by evaluations of the efficiency of processes and the effectiveness of systems of internal control.

A robust administration of development assistance programs increases the chances of success in achieving the objectives defined by donors and above all, of meeting the needs of the community. For the beneficiary States, having a robust program in terms of governance and management of funds, increases their chances of receiving grants and resources in support of their development actions.

Internal audit, for the performance needs of public administrations, was gradually exported from the private sector to the public sector. This is the case, for example, of the reforms undertaken under the instigation of New Public Management (Hood, 1995) [8] in the 1980s for most of the Anglo-Saxon countries (United States, England, Australia and New Zealand, etc.). This is also the case for those undertaken in 2002 in France with the adoption of the Organic Law relating to Finance Laws (LOLF) [9].

Our research subject entitled: "Internal Audit and Trust of
Donors from Developing Countries: Case of Benin" wants to research and explore how, with the reform of the new Organic Law relating to Finance Laws (LOLF) in Benin, internal audit has boosted the trust of donors (Technical and Financial Partners) in Benin.

\section{Research Issues, Questions and Objectives}

\subsection{Research Issues and Questions}

Laws and regulations (and therefore the terms and conditions of Official Development Assistance - ODA) vary according to the donors, which increases the complexity of program administration and allocation management.

In terms of illustrations of the use of Public Development Aid (PDA) in the public sector, we can cite for example:

1) Respond to public policy objectives;

2) Stimulate a sector or the economy;

3) Support actions, including research and investment projects;

4) Provide public services, particularly in health and education;

5) Produce goods, such as medicines; intellectual property, such as patents; and infrastructure, such as highways, schools, homes or hospitals.

As effective as they are, Official Development Assistance is inherently risky because donors generally have only an imperfect knowledge of the beneficiary countries and it is not always possible for them to check the quality of goods and services before or after the decision to allocate aid or loans. This level of risk can depend on many factors: the amount of resources committed, the share of new actions and innovations, the financial situation of the beneficiary State and the quality of its governance, its track record in the management of similar funds and in dealing with grants of comparable value (and perhaps of comparable complexity), etc. However, well-managed risk-taking requires avoiding exaggerated risk aversion by ensuring a fair balance of risks between donors and the recipient state.

Risks, particularly those of donors, include:

1) failure to achieve the objectives of official development assistance programs, such as the provision of services or goods provided to the final beneficiaries;

2) non-compliance with laws and regulations;

3) the allocation of aid to a fraudulent beneficiary or through corrupt practices;

4) damage to reputation resulting from the occurrence of one of these risks.

The International Reference Framework for Professional Internal Auditing Practices (CRIPP, 2017) [10] has published guidelines, which are intended to help internal auditors in the public sector to plan and carry out insurance and advisory assignments relating to Public Development Aid (PDA). This document provides information on the nature and life cycle of funds to help internal auditors, managers and 
administrators of grants to understand, assess, anticipate critical risks related to the administration of allocated funds and the management of attributions and respond to them effectively. With regard to grants, internal auditors and other professionals should carefully study the laws and regulations with which development assistance program stakeholders must comply during the program administration and allocation management processes.

Our problem is based on a main question which is as follows: What is the impact of internal audit on the trust of donors from developing countries?

This main question is divided into two (02) specific questions:

1) What is the impact of internal audit on the performance of public administrations in Benin?

2) What is the impact of the performance of public administrations on the trust of Benin's donors?

\subsection{Research Objectives}

The main objective of our research work is to: Determine the impact of internal audit on the trust of donors in Benin. It has two specific objectives:

1) Measure the impact of internal audit on the performance of public administrations;

2) Evaluate the influence of the performance of public administrations on the trust of Benin's donors.

\section{Literature Review and Research Hypotheses}

\subsection{Review of Related Literature}

For Gambetta (1988) [11], what has changed in the social sciences in recent times has not been the recognition of the importance of trust in social and economic processes; it is the fact that we are now trying to scientifically demonstrate its importance, without giving in to theoretical or empirical difficulty. Thus, if Arrow (1972) [12] appears to attribute confidence to capital importance in the economic system, he does not specify how to measure it exactly. However, if the theoretical approaches to trust are, for some, unsatisfactory and questionable, the empirical methods are even more so. There are essentially two ways of measuring trust, which often correspond in practice respectively to the notions of special trust and generalized trust: experiences and surveys. The main shortcoming of the experiments, which try to assess the trust of individuals, which we will only pass over here, seems to be to interpret either the fact of taking a risk in a repeated game or not, or the fact that agents cooperate, like the mark of trust, which amounts to confusing the effect and the cause (on this question, we refer to Glaeser et al., 2000) [13]. The measurement of generalized trust is even more problematic. It is mainly based on opinion surveys, called "value surveys", and on a specific question of these surveys. According to Cook, Levi and Hardin (2009) [14], the question, particularly poorly formulated and imprecise, is at the origin of the theoretical confusion which permeates the concept of generalized trust. The original generalized trust question, which the General Social Survey (GSS) of the National Opinion Research Center has posed to American citizens since the late 1950s, can be expressed as follows: "In general, would you say that you can trust most people or that you can never be too careful in dealing with others? "; this question was taken up in the World Values Survey (WVS), a survey of values carried out in different countries of the world since the 1980s, in a slightly different form, at least in the survey questionnaire of the last wave dating from 2000: "In general, would you say that you can trust most people or that you have to be very careful when dealing with others?"

Beyond the differences in wording between the two questions, we immediately measure their nebulous nature: "in general", "would you say", "most people", "relationships with others". As Hooghe and Reeskens (2007 [15] put it, "when you look closely at this question, almost all words are problematic". But the authors go further in their critical approach: using the results of the European Social Survey (another survey of values relating to European countries), which asks the same question, they show that it did not the same meaning in the different countries, which deprives international comparisons of generalized confidence levels. Glaeser et al. (2000) [13] and Alesina and La Ferrara (2002) [16] are also cautious about the interpretations that can be drawn from these surveys. For Uslaner (2003) [17], a supporter, it is true, of the generalized approach to trust, this question is, on the contrary, well formulated and really makes it possible to capture trust of a different order than trust reduced to the family, community or professional. What is more, despite glaring methodological limitations, the available studies show that this indicator is relatively stable over time, as Putnam already thought (see below). There is therefore a lively debate on the reliability of the generalized confidence measure. And in fact, the confidence to be placed in this formulation seems to have to be very limited, because, as Nannestad (2008) [18] writes, not only, probably, "nobody trusts everyone", but, moreover, "Nobody trusts everyone about everything". The problem is therefore to determine to what acceptation of trust the respondents refer when they answer the question of generalized confidence. Hardin (2006) [1] is even more radical; in his eyes: "there is little to learn about trust", by consulting the value surveys. Does this judgment close the quantitative debate on trust? According to Dasgupta (1988) [19], on the contrary, it deserves to be prosecuted. Because even if no reliable unit of measure exists for trust, one can gauge its value to the point that the author proposes to consider trust as a "commodity", certainly of a particular and "fragile" type, as the know or information, but a commodity all the same.

Several authors (Proulx and Brière (2014) [20] Delville (2012) [21], Gabas (2013) [22], Navarro-Flores (2007 [23]), Lebovics (2007) [24], Ika (2007) [25]) have addressed the reflection on donors also called Technical and Financial Partners (TFP), Non-Governmental Organization (NGO) and project management, but in different ways; either by giving 
priority to the management of the development aid made available by the PTFs, the participation of the beneficiaries in projects financed by the TFP, the place of NGOs in development projects, whether from the North or the South, and trust of the PTFs.

We (the rest of us) approach this issue from the angle of donor trust in state institutions and in the management of the resources made available. To better understand how States take ownership of TFP projects without being involved in their conception and planning, we must first understand what the literature tells us about States as a whole and their mandate in relation to actions. of development.

States are at the intersection of relations between local communities and development, economic and social, civil society and the North-South relationship. Historically, it is with the aid of developing countries that the best known of international organizations devote their activities. The recognition of the status of these organizations by major international bodies is a time and an opportunity for professionalization for them.

\subsection{Research Hypotheses}

To set the theoretical framework for our hypotheses, we used agency theory (Jensen \& Meckling, 1976 [26]; Chow, 1982 [27]; Watts \& Zimmerman, 1983 [28] and Roy, 1996 [29]) and stakeholder theory (Freeman, 1984) [30].

The central hypothesis is that internal audit improves the trust of state donors. There are two secondary hypotheses which are presented as follows:

1) Internal audit positively influences the performance of public administrations in Benin.

2) The performance of public administrations positively influences the confidence of donors in Benin.

\section{Methodological Approach}

After an in-depth review, we proceeded to the definition and the constitution of a (01) representative panel of Benin's donors (Technical and Financial Partners); basic panel on which our research work relates. Our study for Benin covered all the ministerial departments of the central administration. Indeed, the ministerial departments, as part of the implementation of the new Organic Law relating to Finance Laws (LOLF) reform in Benin, are the preferred areas of execution and implementation of the internal audit process.

To test and validate the above formulated hypotheses, we opted for the "Doubles Differences" statistical model (Jerzy Neyman, 1923 [31]; Donald Rubin, 1974 [32] in order to be able to validate or invalidate our research hypotheses with certainty.

\subsection{Presentation of the Statistical Model of Double Differences}

The double difference model (or difference in difference method) is a statistical method used to estimate the effect of a treatment and consists in comparing the difference between the control group and the treatment group before and after the introduction of the treatment. The processing within the framework of our research work concerns the implementation of internal audit in public administrations in Benin. This double difference method is notably used in the evaluation of public policies to estimate the effect of a policy within the theoretical framework of the causal model of Neyman-Rubin (Jerzy Neyman, 1923) [31] and Donald Rubin (1974) [32].

The canonical model of assessment was introduced by Rubin in 1974. This fairly general model is suited to the situation in which treatment may or may not be administered to an individual. The term treatment refers to the first works that made it possible to develop this conceptual framework, work which concerned the evaluation of the effectiveness of treatments in the medical field. Although it is not the most appropriate, it is used in econometrics to qualify a public intervention, a tax reform, a subsidy policy, a training program, or even a social assistance program that one seeks to assess. Formally, we assume that, for each of the individuals $i$ in a sample of size $N$, we observe the following set of random variables. Access to the program (i.e. here the implementation of internal audit) is represented by a random variable $\mathrm{T}$, which takes the value 1 if the individual accesses the program (here the departments), 0 if this is not the case (the case of the Municipalities of Benin in which the internal audit is not implemented). The effectiveness of the program is measured through an outcome variable, noted Y.

In fact, Rubin's model is based on the existence of two latent outcome variables, denoted $\mathrm{Y} 1$ and $\mathrm{Y} 0$, depending on whether the individual receives the treatment $(\mathrm{T}=1)$ or not $(\mathrm{T}=0)$. These variables correspond to the potential outcomes of the program. They are never simultaneously observed on the same date for the same individual. Thus, for a treated individual, Y1 is observed while $\mathrm{Y} 0$ is unknown. In this case, the variable $\mathrm{Y} 0$ corresponds to the result that would have been achieved if the individual had not been treated. We also say that the variable $\mathrm{Y} 0$ represents the counterfactual result. For an untreated individual, we observe on the contrary $\mathrm{Y} 0$, while Y1 is unknown. The observed outcome variable can therefore be deduced from the potential variables and from the relationship treatment variable:

\section{IMPACT $=($ YT after - YT, before $)-($ YC, after- YC, before $)$}

with $T=$ Implementation of internal audit, $C=$ No implementation of internal audit, after $=$ value of $Y$ after the reform (After implementation of internal audit, 2019) and before $=$ the value taken by $Y$ before the reform (Before the implementation of internal audit, 2016). 


\subsection{Constitution of Treatment Groups and Control of the Statistical Model of Double Differences}

We have set up two groups. The Processing Group: the structures of the central administration in which the internal audit is set up (the Ministries) and the Control Group: the structures of the local administration in which the internal audit is not put in place (the Commons). The periods are as follows: Before-reform period: 2014-2016 and After-reform period: 2017 - 2019.

For our research panel, two research groups have been set up. The Treatment Group 100 individuals composed of TFP (Donors of the Central Administration). The Control Group of 100 individuals made up of TFP (Technical and Financial Partners) who finance the Local Government Structures in which Internal Audit has not yet been implemented.

Numbered questionnaires were administered to each of the groups in our research panel according to the schedule below. From March to October 2016 we collected relevant data before the implementation of internal audit. From March to July 2019, we carried out the second series of surveys to assess the impact of internal audit. We studied the same groups from 2016 in 2019 with the same questionnaires from 2016. For us, this involves studying the data before and after the implementation of Internal Audit for the Treatment Group and for the Group Control of our donor panel.

\section{Presentation and Discussion of Research Results}

\subsection{Presentation and Discussion of Research Results for the Validation of Hypothesis $N^{\circ} 1$}

The sub-variables resulting from the questions asked during our survey work are presented as follows in the table below:

Table 1. Table of sub-variables.

\begin{tabular}{|c|c|c|c|c|}
\hline Variable Questions or Sub-variables & Question 1 (q1) & Question 2 (q2) & Question 3 (q3) & Question 4 (q4) \\
\hline Performance of Public Administrations & $\begin{array}{l}\text { Quality of reception of } \\
\text { TFPs in public } \\
\text { administrations }\end{array}$ & $\begin{array}{l}\text { Quality of public } \\
\text { administration } \\
\text { services }\end{array}$ & $\begin{array}{l}\text { Quality of e-Services } \\
\text { (Online service) of public } \\
\text { administrations }\end{array}$ & $\begin{array}{l}\text { Relational quality and } \\
\text { responsiveness of public } \\
\text { administration agents }\end{array}$ \\
\hline
\end{tabular}

Source: Developed by us using data from survey questionnaires.

All of the above listed items were rated on a scale of 0 to 5 , namely:

Table 2. Notation of the sub-variables.

\begin{tabular}{ll}
\hline Element & Rating \\
\hline Strong satisfaction & 5 \\
Correct satisfaction & 4 \\
Poor satisfaction & 1 \\
Unacceptable satisfaction & 0 \\
\hline
\end{tabular}

Source: Developed by us using data from survey questionnaires.

On the basis of the data collected during our surveys, we calculated and made statistical tests on the basis of means and standard errors, which are estimated by linear regression. The cumulative data from the statistical tables generated by the STATA software are presented as follows in the table below:

Table 3. Summary of intergroup differences and double differences in the performance of public administrations.

\begin{tabular}{|c|c|c|c|c|c|c|c|c|}
\hline Variable & Sub-variables & $\begin{array}{l}\text { Inter-group Difference } \\
\text { (PROCESSING group - } \\
\text { control Group) }\end{array}$ & $\begin{array}{l}\text { Number of } \\
\text { observations }\end{array}$ & $\begin{array}{l}\text { Differences } \\
2019\end{array}$ & $\begin{array}{l}\text { Differences } \\
2016\end{array}$ & $\begin{array}{l}\text { Doubles } \\
\text { Differences }\end{array}$ & T-stat & $\begin{array}{l}\text { R- } \\
\text { square }\end{array}$ \\
\hline \multirow{3}{*}{$\begin{array}{l}\text { Performance of } \\
\text { Public } \\
\text { Administrations }\end{array}$} & $\begin{array}{l}\text { Quality of reception of TFPs in } \\
\text { public administrations }\end{array}$ & $\begin{array}{l}\text { Intergroup difference } \\
\text { (Ministries - Commons) }\end{array}$ & 200 & 3.100 & 0.910 & 2.190 & $8.43 * *$ & 0.50 \\
\hline & $\begin{array}{l}\text { Quality of public } \\
\text { administration services }\end{array}$ & $\begin{array}{l}\text { Intergroup difference } \\
\text { (Ministries - Commons) }\end{array}$ & 200 & 2.670 & 0.710 & 1.960 & $6.64 * *$ & 0.36 \\
\hline & $\begin{array}{l}\text { Relational quality and } \\
\text { responsiveness of public } \\
\text { administration agents }\end{array}$ & $\begin{array}{l}\text { Intergroup difference } \\
\text { (Ministries - Commons) }\end{array}$ & 200 & 2.430 & -0.290 & 2.720 & 9.78 & 0.37 \\
\hline
\end{tabular}

Source: Developed by us using data from tables generated by statistical tests using the "Double Differences Model". 
of internal audit on the performance of public administrations, we will assess the impact by sub-variables listed more high.

We have directed our research work with Technical and Financial Partners (TFP) of the Beninese State, to analyze their degree of trust and their perception about the performance of public administrations.

1) Quality of reception in public administrations

The average of the scores granted by the Technical and Financial Partners (TFP) of the ministries and the commons, in terms of the quality of the reception in the Ministries and the commons, establishes differences of 0.910 and 3.100 respectively in 2016 and 2019. It there is therefore a double difference of 2,190. Internal audit therefore had a positive impact on the quality of the reception of TFP in public administrations. The correlation coefficient stands at 0.71 .

2) Quality of public administration services

With regard to the quality of public administration services, the difference in the average score given by respondents from the Technical and Financial Partners of the Beninese State and that given by respondents from the commons amounted to 0.710 in 2016 . This same difference amounts to 2,670 in 2019, after the implementation of internal audit. There is therefore a double difference of 1,960, a significant double difference. In 2019, the Technical and Financial Partners have a good appreciation of the quality of the services of public administrations.

3) Quality of online services for public administrations

At this level, the difference in the average of the marks awarded by the Technical and Financial Partners is 0.280 in 2016 and 2.850 in 2019 , a double difference of 2.570 with the Student's t amounting to 9.48. The impact of internal audit is therefore positive on the quality of online services of public administrations, perceived by the Technical and Financial Partners.

4) Relational quality and responsiveness of public administration agents

The difference in the average score awarded by the Technical and Financial Partners, in terms of relational quality and responsiveness, amounted to -0.290 in 2016 and 2.430 in 2019 , a double difference of 2.720 , which is significant with Student of 9.78, which reveals the significance of the test. There is therefore a positive impact of internal audit on relationship quality and responsiveness. The Technical and Financial Partners therefore have a good perception of the relational quality and the reactivity of the agents.

\section{SUB-CONCLUSION 1}

In light of the above analyzes and comments on the results obtained at the level of Technical and Financial Partners, we note that internal audit had a positive impact on the 4 subvariables of the main variable "Performance of public administrations". Internal audit therefore positively influences the performance of public administrations in Benin. The hypothesis $\mathrm{N}^{\circ} 1$ of our research work is validated.

\subsection{Presentation and Discussion of Research Results for the Validation of Hypothesis $\mathrm{N}^{\circ} 2$}

The sub-variables resulting from the questions asked during our survey work are presented as follows in the table below:

Table 4. Table of sub-variables.

\begin{tabular}{llll}
\hline Variables & Questions or Sub-variables & Question 2 (q2) & Question 3 (q3) \\
\hline $\begin{array}{lll}\text { Trust of Technical and Financial } \\
\text { Partners } \text { or Funders }\end{array}$ & $\begin{array}{l}\text { Quality of } \\
\text { implementation of } \\
\text { development aid } \\
\text { programs }\end{array}$ & $\begin{array}{l}\text { Achievement of the } \\
\text { objectives of development } \\
\text { assistance programs }\end{array}$ & $\begin{array}{l}\text { Transformation of the } \\
\text { socio-economic reality of } \\
\text { beneficiaries of } \\
\text { development aid programs }\end{array}$ \\
\hline
\end{tabular}

Source: Developed by us using data from survey questionnaires.

The table above will allow us to assess the impact of the performance of public administrations on the trust of donors:

Table 5. Summary of intergroup differences and double differences in Donor's trust.

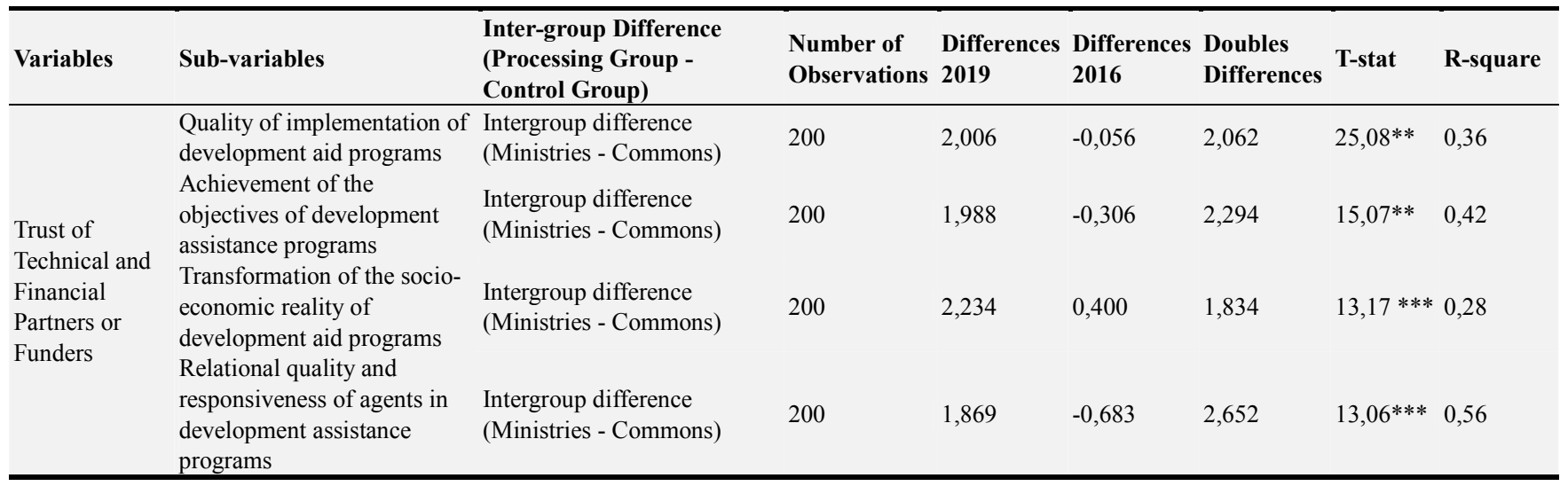

Source: Developed by us using data from tables generated by statistical tests using the "Double Differences Model". 
1) Quality of implementation of development aid programs

The average of the marks granted by the Technical and Financial Partners, of the ministries and the Commons, at the level of the quality of implementation of the programs, establishes a double difference of 2,062 with a Student's t of 25.08. The performance of public administrations in Benin therefore had a positive impact on the quality of implementation of development aid programs in Benin.

2) Achievement of the objectives of development assistance programs

At the level of this sub-variable, the inter-group differences give a double difference of 2.294. The performance of public administrations in Benin therefore had a positive impact on the achievement of the objectives of development aid programs.

3) Transformation of the socio-economic reality of beneficiaries of development aid programs

At the level of the beneficiaries of the programs, the difference in the average of the marks granted by the beneficiaries of the ministries and the local communities gives a double difference of 1.834. The impact of the performance of public administrations in Benin is therefore positive on the transformation of the socio-economic reality of the beneficiaries of development aid programs.

4) Relational quality and creativity of agents of development assistance programs

The difference in the average of the scores awarded by the beneficiaries of the programs of the ministries and the local communities, in terms of relational quality and responsiveness, amounted to -0.683 in 2016 and to 1.869 in 2019 , i.e. a double difference of 2.652 in $5 \%$ threshold with a Student's $t$ of 13.06. There is therefore a positive impact of the performance of public administrations in Benin on the quality of relationships and responsiveness.

\section{SUB-CONCLUSION 2}

In view of the above analyzes and comments, we note that the performance of public administrations in Benin had a positive impact on the 4 sub-variables of the variable "Trust of Technical and Financial Partners". The performance of public administrations has a positive impact on the trust of donors. The hypothesis $\mathrm{N}^{\circ} 2$ of our research work is also validated.

This result is confirmed by the numbers in the table of external financial resources of Benin from 2009 to 2019:

Table 6. Table of Benin's external financial resources (in billions of FCFA).

\begin{tabular}{|c|c|c|c|c|c|c|c|c|c|c|c|}
\hline ELEMENTS & 2009 & 2010 & 2011 & 2012 & 2013 & 2014 & 2015 & 2016 & 2017 & 2018 & 2019 \\
\hline Total External Resources & 142,6 & 112,4 & 111,5 & 94,2 & 176,2 & 126,5 & 131,4 & 117,0 & 178,5 & 389,5 & 563,3 \\
\hline Project Financing & 80,7 & 76,0 & 119,1 & 87,7 & 154,3 & 135,1 & 160,3 & 121,1 & 178,5 & 218,0 & 231,1 \\
\hline Donations Projects & 28,8 & 19,2 & 76,8 & 43,4 & 28,1 & 35,9 & 28,8 & 26,1 & 43,3 & 37,0 & 67,5 \\
\hline Loans Projects & 52,0 & 56,8 & 42,3 & 44,3 & 126,2 & 99,2 & 131,4 & 95,0 & 135,3 & 181,0 & 163,6 \\
\hline Program Financing & 71,3 & 52,2 & 10,3 & 31,5 & 50,1 & 18,0 & 0,0 & 20,2 & 51,7 & 200,3 & 45,4 \\
\hline Program Donations & 71,3 & 28,9 & 10,3 & 31,5 & 12,8 & 8,2 & 0,0 & 8,5 & 14,0 & 17,5 & 25,3 \\
\hline Program Loans & 0,0 & 23,3 & 0,0 & 0,0 & 37,3 & 9,8 & 0,0 & 11,6 & 37,8 & 182,8 & 20,1 \\
\hline
\end{tabular}

Source: National Representation of the International Monetary Fund (IMF) in Benin (Data 2019).

Reviewing the numbers in this table, we find the following:

1) The external financial resources mobilized amounted to 131.4 billion FCFA and 117.0 billion FCFA, respectively in 2015 and 2016; either before the implementation of internal audit in public administration in Benin

2) The external financial resources mobilized amounted to
389.5 billion FCFA and 563.3 billion FCFA, respectively in 2018 and 2019; either after the implementation of internal audit in public administration in Benin

3) Between 2016 and 2019, there is a growth rate of $381.45 \%$, which is considerable.

This observation is illustrated in the figure below:

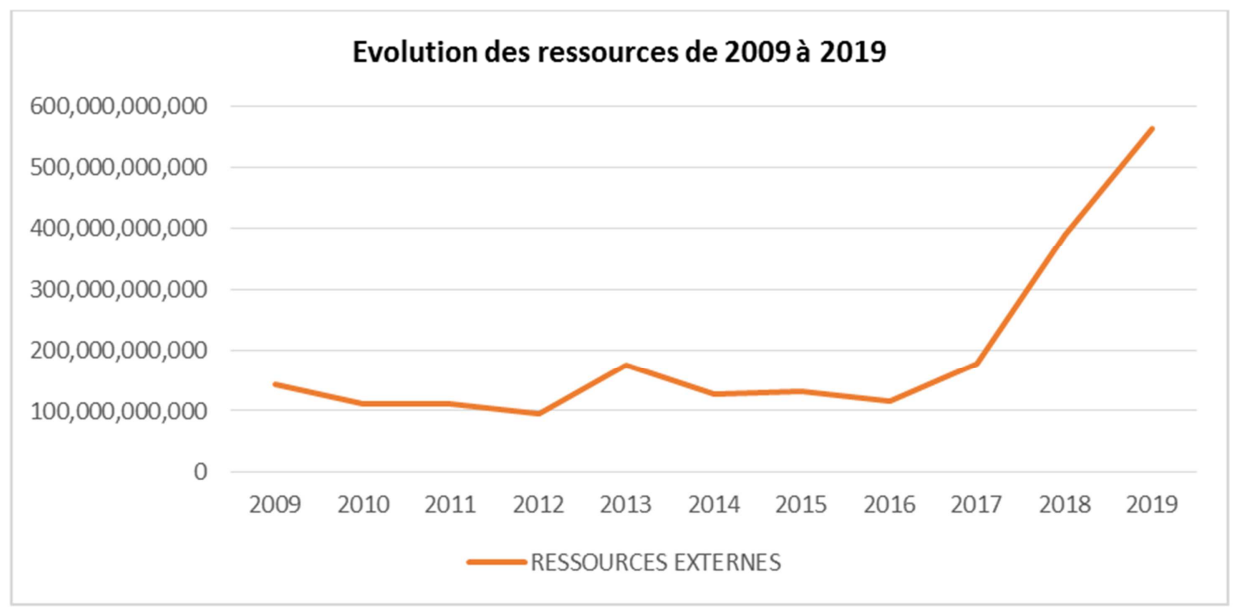

Figure 2. Evolution of the State's external financial resources. 
The positive impact of internal audit on the trust of Benin's donors through the performance of public administrations was especially manifested by a substantial increase in Development Assistance and Loan Agreements of Technical and Financial Partners. This is a direct manifestation of the trust that donors have placed in the Beninese state.

\section{Conclusion and Recommendations}

The low trust of donors in developing countries for the management of Public Development Aid (PDA) and Loans, led us to investigate on the theme: "Internal audit and Trust of Donors in Developing Countries: Case of Benin". Under the assumption that a substantial internal audit improves the performance of public administrations, we have resorted to agency theory Jensen \& Meckling, 1976 [27]; Chow, 1982 [28]; Watts \& Zimmerman, 1983 [29] and Roy, 1996 [30]) and stakeholder theory (Freeman, 1984) [31]. The double difference method (or difference in difference method) is the statistical method used to estimate the effect of a treatment. Our research shows that internal audit has a positive impact on the 4 sub-variables of the variable "Performance of public administrations". Internal audit therefore positively influences the performance of public administrations in Benin. Hypothesis $\mathrm{N}^{\circ} 1$ has been validated.

The study also reveals that the performance of public administrations in Benin has a positive impact on the 4 subvariables of the variable "Donor Trust". The performance of public administrations has a positive impact on the Trust of Donors in Benin. Research hypothesis $\mathrm{N}^{\circ} 2$ is also validated. The implementation of the Beninese public administration success model is therefore recommended for all public administration structures in African countries in general and that of Benin in particular. It is therefore up to Developing Countries to generalize the implementation of internal audit at the level of all public administrations to strengthen the trust of donors.

\section{References}

[1] Hardin R., 2006, Trust, Cambridge, Polity Press.

[2] Putnam R. D., 1993, Making Democracy Work: Civic Traditions in Modern Italy, Princeton, Princeton University Press.

[3] Putnam R. D., 1995, «Bowling Alone: America's Declining Social Capital», The Journal of Democracy, 6,1, pp. 65-78.

[4] Fukuyama F., 1995, Trust: The Social Virtues and the Creation of Prosperity, New York, The Free Press.

[5] Amar Bhattacharya and Mattia Romani, 2013, Meeting the Infrastructure Challenge: The Case fora New Development Bank. Global Economic Governance Seminar.

[6] La Directive $\mathrm{N}^{\circ} 06 / 2009 / \mathrm{CM} / \mathrm{UEMOA}$ portant lois de finances.
[7] Loi Organique $N^{\circ}$ 2013-14 relative aux Lois des Finances (LOLF) en Répubique du Bénin du 27 Septembre 2013.

[8] HOOD Craig (1995), «Contemporary Public Management: A New Global Paradigm?», Public Policy and Administration, Vol. 10, n², pp. 104-117.

[9] Loi Organique $\mathrm{N}^{\circ}$ 2001-692 relative aux Lois des Finances (LOLF) en Répubique Française du $1^{\text {er }}$ Août 2001.

[10] Cadre de Référence International des Pratiques Professionnelles, CRIPP, 2017, de l'Audit Interne.

[11] Gambetta D. (ed.), 1988, Trust: Making and Breaking Cooperative Relations, Oxford: Basil Blackwell.

[12] Arrow K. J., 1972, "Gifts and Exchanges Author (s)», Philosophy and Public Affairs, Vol. 1, n 4, été, pp. 343-362.

[13] Glaeser E. et al., 2000, «Measuring Trust», Quarterly Journal of Economics, 115, pp. 811-41.

[14] Karen S. Cook Margaret Levi Russell Hardin, 2009. Whom Can We Trust?: How Groups, Networks, and Institutions Make Trust Possible. The Russell Sage Foundation Series onTrust.https://www.jstor.org/stable/10.7758/9781610446075.

[15] Hooghe, M. et T. Reeskens, 2007, «Cross Cultural Measurement Equivalence of Generalized Trust. Evidence from the European Social Survey (2002 and 2004)», Social Indicators Research, 81.

[16] Alesina A et E. La Ferrara, 2002, «Who trusts others?», Journal of Public Economics, $\mathrm{n}^{\circ}$ 85, pp. 207-234.

[17] Uslaner, E. M, 2003, «The Moral Foundations of Trust», paper prepared for presentation at Nuffield College, Oxford University, February 14, 2003.

[18] Nannestad P., 2008, "What Have We Learned About Generalized Trust, If Anything?», Annual Review of Political Science, juin, Vol. 11.

[19] Dasgupta P., 1988, " Trust as a commodity » in D. Gambetta (ed.), Trust: Making and Breaking Cooperative Relations, Londres, Basil Blackwell.

[20] Proulx and Brière, 2014, Caractéristiques et succès des projets de développement international: que peuvent nous apprendre les gestionnaires d'ONG? Canadian Journal of Development Studies/Revue canadienne d'études du développement, Vol. 35 N² JUIN 2014. PP 249-264.

[21] Lavigne Delville Philippe, Affronter l'incertitude?: les projets de développement à contre-courant de la "révolution du management de projet". Revue Tiers Monde, 2012, (211), p. 153-168. ISSN 1293-8882.

[22] Gabas J. J., 2009, «Référentiels, développement et politiques de coopération», in Techniques financières et développement, Epargne sans frontière, $\mathrm{n}^{\circ}$ 92, septembre, Paris.

[23] Navarro-Flores, 2007. «L'économie sociale, l'économie solidaire et les organisations de coopération internationale: vers une meilleure compréhension du lien local-international de l'alter-mondialisation», présentation à la Première conférence mondiale sur la recherche en économie sociale: Bâtir les communautés: L'économie sociale dans un monde en mouvement, Octobre 22-25, 2007, Victoria, BC, Canada (présentation le 26 octobre 2007). 
[24] Lebovics, 2007 - Bringing the Empire Back Home. France in the Global Age, Durham-Londres, Duke University Press, 2004, 232 p. | Imperialism and the Corruption of Democracies, Durham-Londres, Duke University Press, 2006, 172 p.

[25] Ika (2007), Les agences d'aide au développement font-elles assez en matière de formulation des facteurs clés de succès des projets?

[26] Jensen and Meckling, W. H., "Theory of the Firm: Management Behaviour, Agency Costs and Ownership Structure", Journal of Financial Economics, Vol. 3 No. 3, 1976, 1994, pp. 305-60.

[27] Chow, C. W, 1982, The Demand for External Auditing: Size, Debt and Ownership Influences. Accounting Review, 57, 272-291.

[28] Watts \& Zimmerman, 1983, Agency Problems, Auditing, and the Theory of the Firm: Some Evidence. The Journal of
Law and Economics 26 (3): 613-33 February 1983 with 8,411 Reads.

[29] Roy, B. (1996) Multicriteria Methodology Goes Decision Aiding. Kluwer Academic Publishers, Berlin.

[30] Freeman, 1984, A Stakeholder Approach to Strategic Management, SSRN Electronic Journal January 2001 with 135,214 Reads.

[31] Rubin, Donald B, On the Application of Probability Theory to Agricultural Experiments. Essay on Principles. Section 9.] Comment: Neyman (1923) and Causal Inference in Experiments and Observational Studies. Statist. Sci. 5 (1990), no. 4, 472-480. doi: 10.1214/ss/1177012032. https://projecteuclid.org/euclid.ss/1177012032.

[32] Rubin, D. B, 1974. Estimating causal effects of treatments in randomized and nonrandomized studies. Journal of Educational Psychology, $66 \quad$ (5), 688-701. https://doi.org/10.1037/h0037350. 